\title{
母子に発現した鎖骨頭蓋異骨症
}

\author{
升井一朗・川尌俊明・長尾博道 \\ 本田武司・古本克磨・森 進一郎*
}

\section{Cleidocranial dysostosis observed in mother and child}

\author{
Ichiro Masui - Toshiaki Kawasaki - Hiromichi Nagao \\ Takeshi Honda - Katsuma Kомото • Shinichiro MoRI*
}

\begin{abstract}
Cleidocranial dysostosis is an uncommon condition characterized by ossification disturbance of the clavicles and skull, oral and dental anomalies, together with hereditary characteristics. It is described in foreign countries where more than 600 cases have been presented, out of which a number of familial occurrences have been reported. However, relatively few familial cases have been reported in Japan.

We report here an experience with cleidocranial dysostosis observed in mother and child. A 39-year-old woman visited this hospital complaining of an oppressive pain on the gingiva at the region of $\sqrt{23}$. An orthopantomogram showed 16 impacted teeth including 5 supernumerary teeth in the jaws. Further examinations revealed incomplete ossification of the cranial sutures, hypoplasia of facial bones, mandibular prognathism, high palatal vault, partial defect of the clavicles, and other findings. From the family history it was found that the second of two sons, a 10-year-old boy, had a delayed dentition of the permanent teeth. Radiographic and physical examinations of him disclosed open fontanel and incomplete ossification of the cranial sutures, delayed eruption of the permanent teeth, total defect of the right clavicle and partial defect of the left one, hypoplastic development of the pelvis, and some other findings.

Additionally, discussions on clinical features with a reference to familial occurrences of this condition based on Japanese literature were made and the results are as follows:

1) Therewas much variety of such characteristic findings as hypoplasia of the skull and clavicles and oral anomalies between the cases which suggested that many incomplete forms of this condition exist.

2) 153 cases of cleidocranial dysostosis were reported in Japan, $50(32.7 \%)$ of which were cases observed in a parent and child were in 25 families. From considerations of existence of incomplete forms and occurrences in siblings, however, further investigations of the patient's family might disclose more familial occurrences.
\end{abstract}

Key words: familial cleidocranial dysostosis

福岡宷科大学口腔外科学第 2 满座

（主任：古本克厢教授）

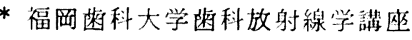

(主任：森 進一郎教授)

The Second Department of Oral Surgery, Fukuoka Dental College (Chief: Prof. Katsuma Komoto)

* Department of Dental Radiology, Fukuoka Dental College (Chief: Prof. Shinichiro Mori)

受付日：昭和59年 7 月 16 日
緒

言

鎖骨頭蓋異育症は頭蓋骨の形成不全，鎖骨の欠損また は形成不全，および歯牙の発育不全と交换期の遅延など を主徵とするまれな症候群であり，1765年, Martin が 先天性鎖骨欠損症としてはじめて報告したといわれてい る 1898年, Marie and Sainton は上記主徵に加えて 


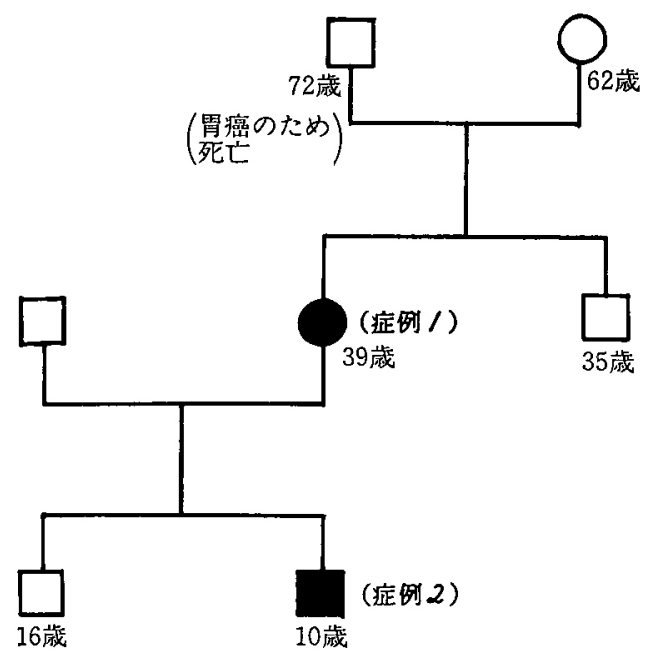

図 1 家系調查

遺云性をあげ, la dysostose cleidocranienne hereditaire と命名し，本疾患の概念を確立した2)，その後，欧米に

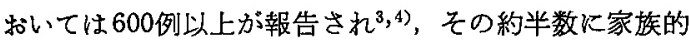
発症を認めたという報告がみられる5,6)，本邦に沶いて は，1918年，藤井の報告が嗃矢とされ7)，現在までに百 十数例が報告されているが，家族的に発症した例は比較 的少ないといわれている8

今回著者らは，母子に発現した本症を経験したので， その概要と文献的考察を合わせて報告する。

$$
\text { 症例 }
$$

\section{症例 1}

患 者: 39歳 女性.

初 診: 昭和58年 2 月

主 訴： $\overline{23}$ 相当部唇側歯肉の圧痛。

来院経由：昭和 57 年 12 月 $\square, \sqrt{23}$ 相当部の骨膜炎 を発症し，某菌科医院を受診して投薬による消炎療法 後，精查のため当科へ紹介されたものである。

既往歴：母親の言によれば，出産は正常分婏で生後 2 か月頃まで虚弱体質であったといわれたが，その後は特 記すべき全身疾患炕䍜患することなく現在まで健康であ る.ただし，永久崡萠出期になっても多数が萠出せず， 約15年前より上下顎に部分床義歯を使用している。

家族歴：患者の父親は72歳時に胃癌のため死亡，母親 は62歳で健在であり，血族結婚ではない，同胞は35歳の 弟 1 人であるが，同胞の家族を含めて骨格系の異常を思 わせるものはいないとのことであった。 また，患者は帝 王切開により 2 人の男児を出産したが，第 2 子(症例 2 ) に本症を認めた。ちななに，第 1 子，16歳，男性につい ても精査を行ったが異常所見は見い出せなかった（図

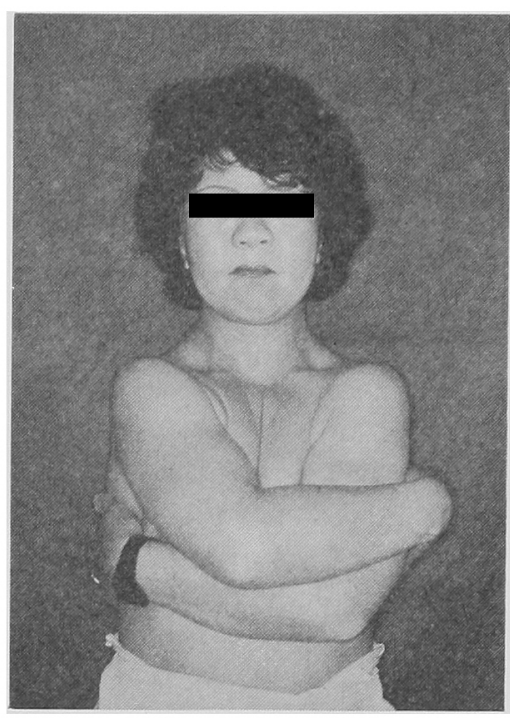

写真 1 上半身所見

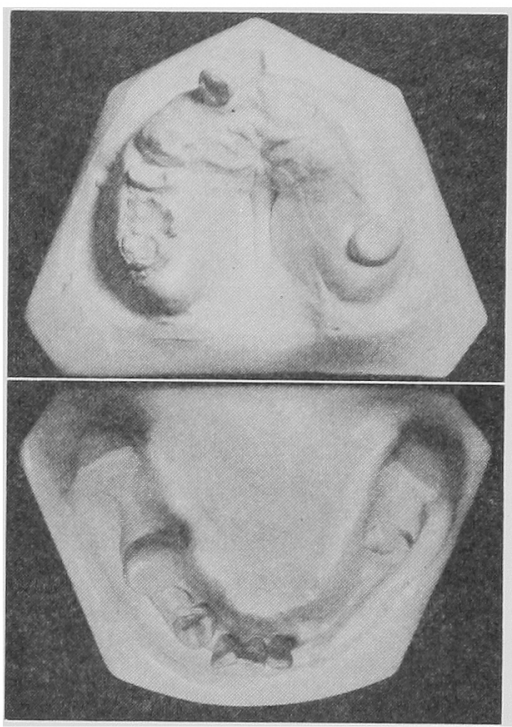

写真 2 上下顎湅列模型

$1)$.

現 症: 身長 $148 \mathrm{~cm}$ ，体重 $47 \mathrm{~kg}$ で，体格は小さい が栄養状態は良好であり, 運動障害, 知能障害は認めら れなかった。 また，両側の肩を苦痛なく前方で接近させ ることができるが，心肺等に異常は認められなかった。

顔貌は左右対称で，前額部がやや突出しており；奥根 部の発育が琹く左右内眼角間がやや広く認められた。 た，中顔面の陌凹と下頂前突様顔貌を呈していた（写真 1 ).

口腔内には 12 本の永久歯と婏期残存した|Cの残根が みられ，平常は上下顝に部分床義歯を使用している，萌 


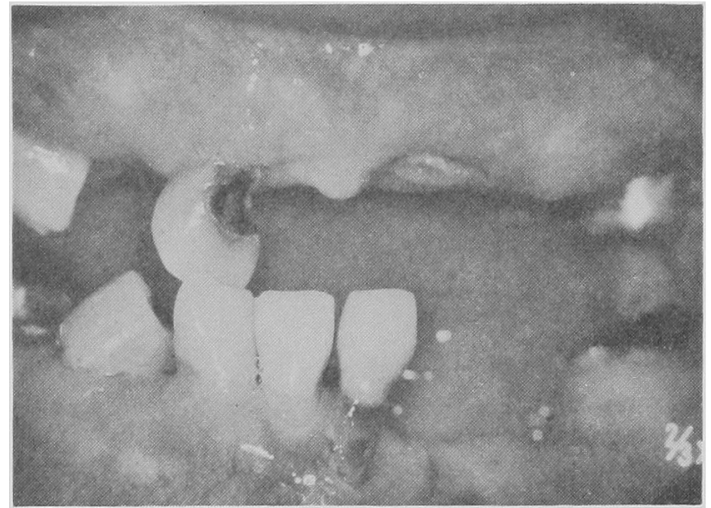

写直 3 口腔内写真

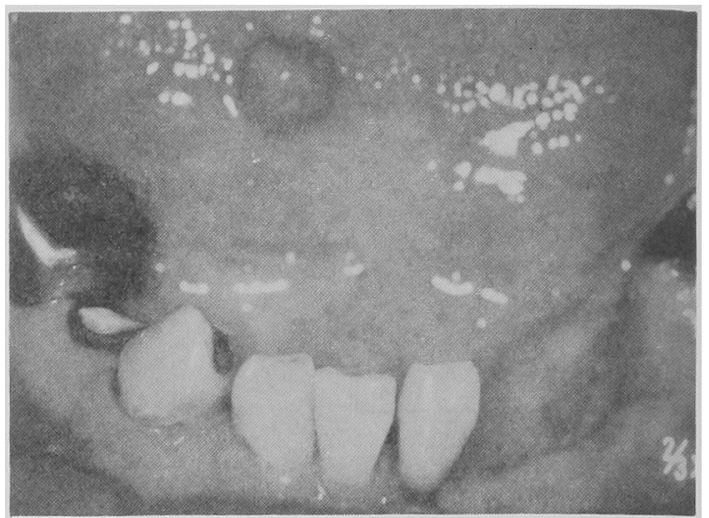

写真 4 舌尖部線維腫

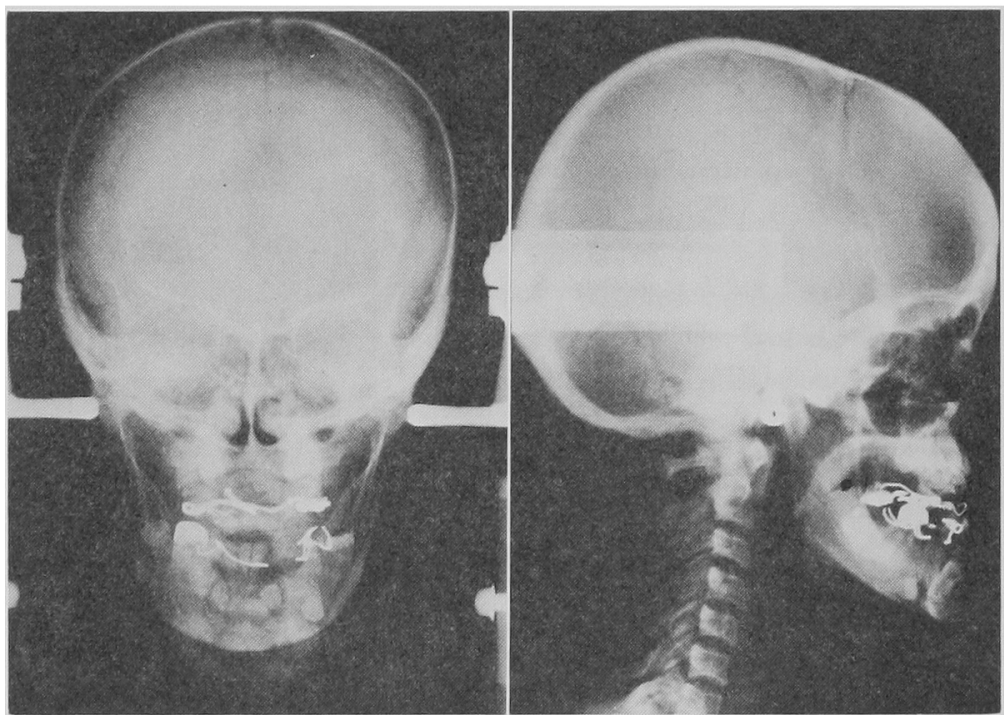

写真 5 頭部X線写真

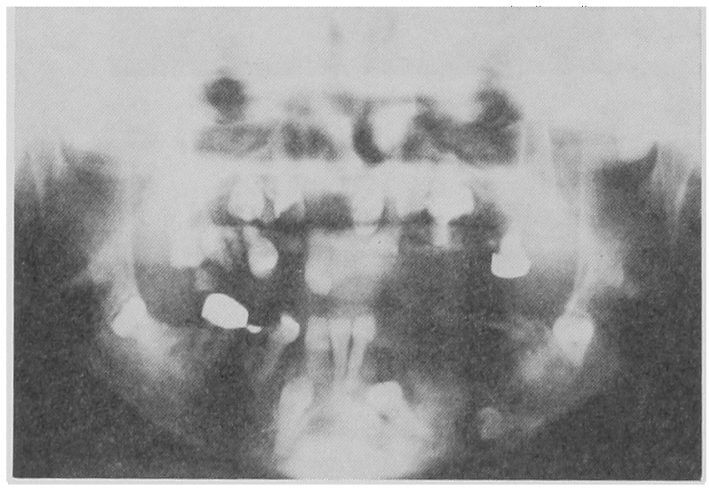

写真 6 オルンパントモ写真
出米のらち， $\frac{76 \mid C}{5} \mid 7$ は残根状態で， $\frac{7}{6}$ には全部被 覆冠が装着され，残りの $\frac{52}{421} \mid 1$ も哃蝕度 $\mathrm{C}_{2}$ であった. 口蓋は高く，正中口蓋縫合に一致して溝状の浅い陌凹を 認めた（写真 2)。また，舌尖部に小豆大，弾性硬，類 円形の無痛性の腫瘤を認めた。他の口腔粘膜は， $\overline{23}$ の 唇側肉軽度の発赤と圧痛を認める以外飞異常所見は みられなかった（写真 3，4）。

$\mathbf{X}$ 線所見 :

（1）頭部および口腔領域

顔面頭蓋は脳頭蓋に比校してやや小さく，上顎洞の発 育も不良で，上顎の劣成長と下䫚前突を思わせた，ま た，矢状縫合，冠状縫合に軽度の閉鎖不全を思わせる透 過像を認め，人字梿合は著しく迂曲しモザイク様の插間 骨が観察された（写真 5 ）. 


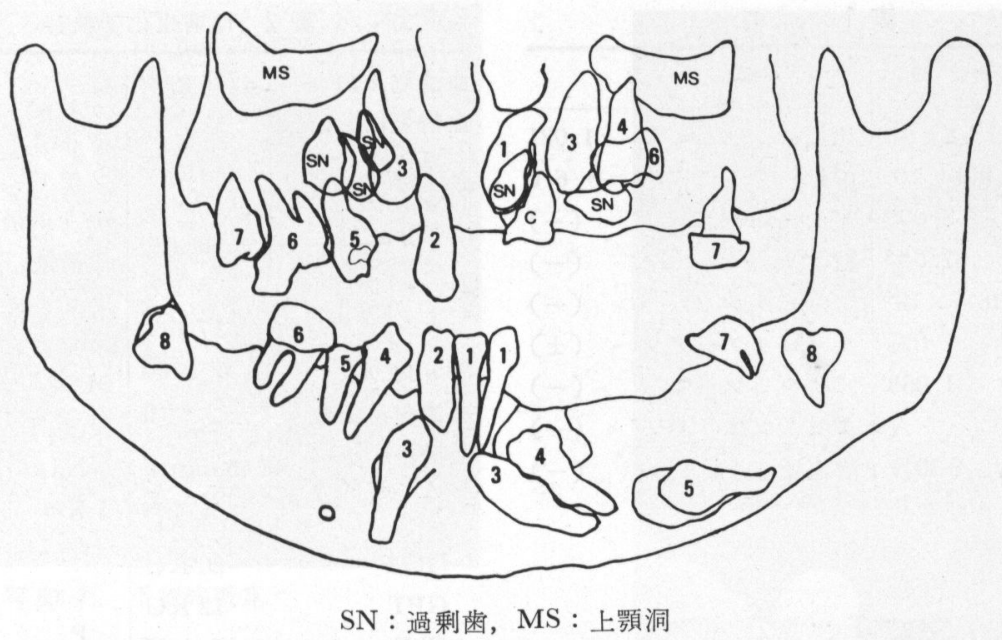

図 2 写真 6 の模式図

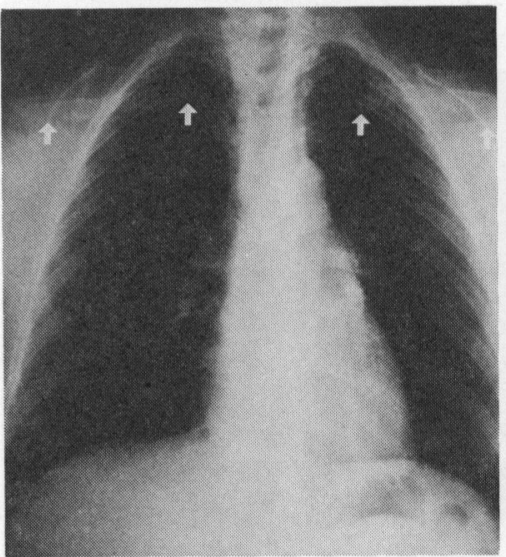

写真 7 胸部 $X$ 線写真

両側鎖骨の内外側端欠損（矢印）

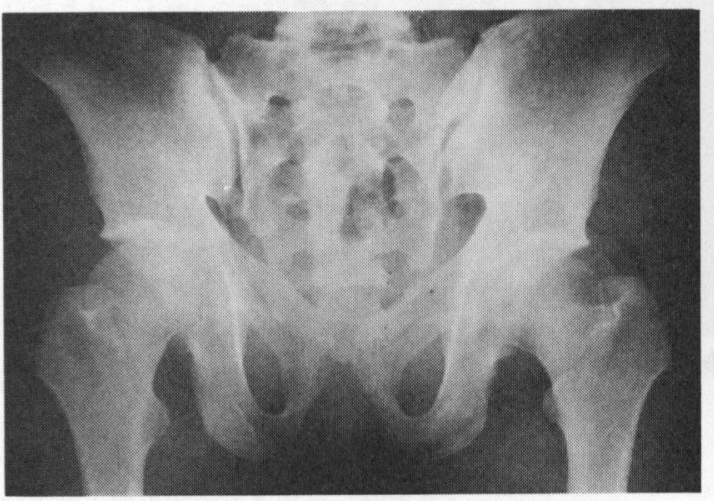

写真 8 骨盤X線写真
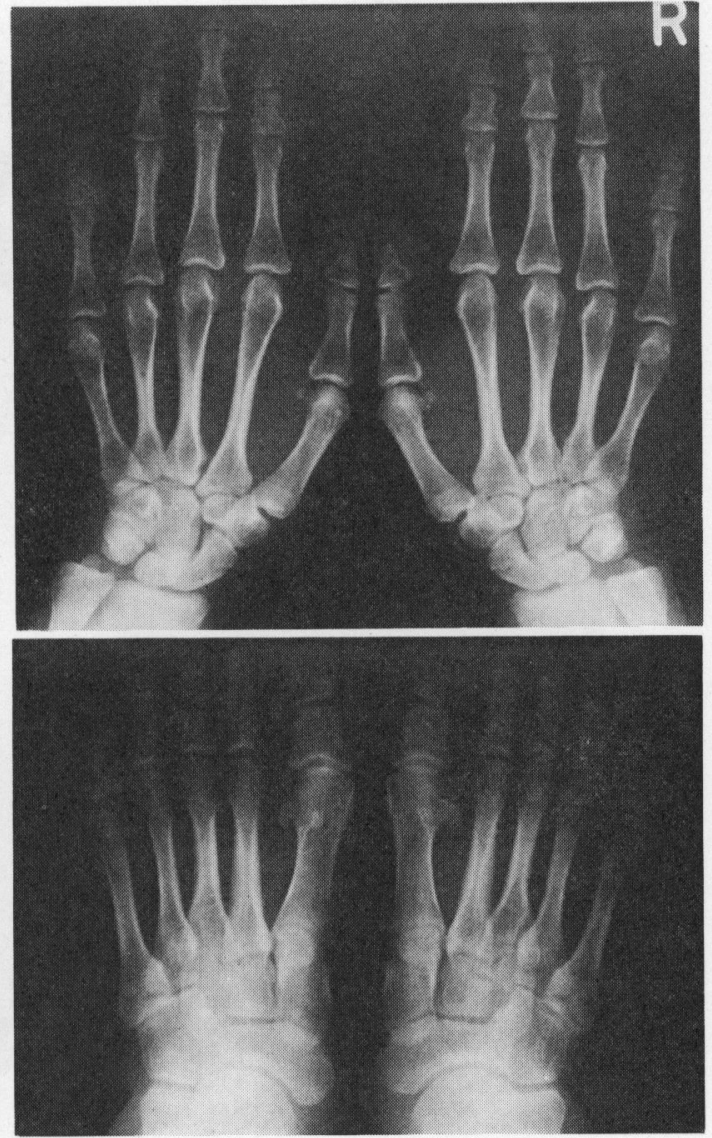

写真 9 手, 足の X線写真 
表 1

\begin{tabular}{|c|c|c|c|}
\hline \multicolumn{2}{|c|}{ 血液一般検査 } & \multicolumn{2}{|l|}{ 尿 検 査 } \\
\hline 血色素量 & $13.8 \mathrm{~g} / \mathrm{d} l$ & 比重 & 1. 021 \\
\hline 赤血球数 & $438 \times 10^{4}$ & $\mathrm{pH}$ & 6.0 \\
\hline 白血球数 & 5,000 & 蛋白 & $(-)$ \\
\hline $\mathrm{Ht}$ 值 & $37.6 \%$ & 糖 & $(-)$ \\
\hline 血小板数 & $28.7 \times 10^{4}$ & ウロビリン & $(-)$ \\
\hline 網赤血球数 & $6 \%$ & ウロビリノーダン & $( \pm)$ \\
\hline 血液比重 & 1. 053 & ビリルビン & $(-)$ \\
\hline 血液型 & A & アセトン体 & $(-)$ \\
\hline 出血時間 & 2 分 30 秒 & 潜血反応 & $(-)$ \\
\hline 凝固時間 & 9 分 0 秒 & & \\
\hline 白血球像 & & & \\
\hline Seg & $36 \%$ & & \\
\hline $\mathrm{E}$ & $2 \%$ & & \\
\hline B & $0 \%$ & & \\
\hline M & $13 \%$ & & \\
\hline Ly & $49 \%$ & & \\
\hline
\end{tabular}

表 2 血清生化学検査

\begin{tabular}{|c|c|c|c|}
\hline \multicolumn{2}{|l|}{$\begin{array}{l}\text { 血清総蛋白 } \\
\text { 血清蛋白分画 }\end{array}$} & $\begin{array}{l}\text { 総コレステ } \\
\text { ロール }\end{array}$ & $156 \mathrm{mg} / \mathrm{d} l$ \\
\hline アルブミン & $61.5 \%$ & $\begin{array}{l}\text { トリグリセ } \\
\text { ライド }\end{array}$ & $48 \mathrm{mg} / \mathrm{d} l$ \\
\hline グロブリン & $5.4 \%$ & $\beta$-リポ蛋白 & $420 \mathrm{mg} / \mathrm{d} l$ \\
\hline & $6.4 \%$ & 血清鉄 & $86 \mu \mathrm{g} / \mathrm{d} l$ \\
\hline & $8.9 \%$ & クレアチン & $1.09 \mathrm{mg} / \mathrm{d} l$ \\
\hline & $17.6 \%$ & クレアチ =ン & $0.68 \mathrm{mg} / \mathrm{d} l$ \\
\hline & 1.60 & BUN & $13 \mathrm{mg} / \mathrm{d} l$ \\
\hline 血清黄疸指数 & 5 & 尿酸 & $3.1 \mathrm{mg} / \mathrm{d} l$ \\
\hline $\begin{array}{l}\text { 血清総 } \\
\text { ビリルビン }\end{array}$ & $0.45 \mathrm{mg} / \mathrm{d} l$ & $\mathrm{Na}$ & $144 \mathrm{mEq} / l$ \\
\hline ALP & $4.1 \mathrm{KAU}$ & $\mathrm{K}$ & $3.8 \mathrm{mEq} / \mathrm{l}$ \\
\hline GOT & $20 \mathrm{KU}$ & $\mathrm{Cl}$ & $106.7 \mathrm{mEq} / l$ \\
\hline GPT & $12 \mathrm{KU}$ & $\mathrm{Ca}$ & $7.8 \mathrm{mg} / \mathrm{d} l$ \\
\hline ChE & $1.12 \Delta \mathrm{pH}$ & $\mathrm{P}$ & $1.6 \mathrm{mg} / \mathrm{d} l$ \\
\hline $\mathrm{LDH}$ & $285 \mathrm{WU}$ & & \\
\hline LAP & 122 GRU & & \\
\hline アミラーゼ & $146 \mathrm{SU}$ & & \\
\hline
\end{tabular}

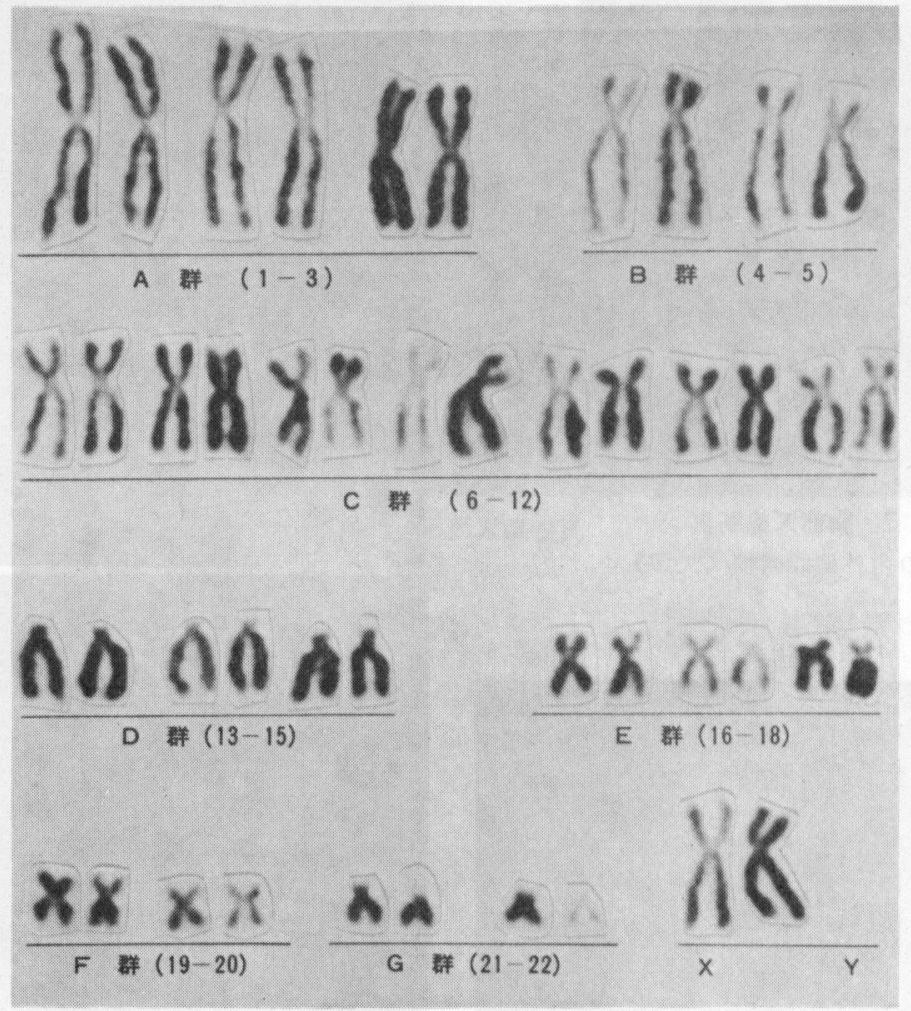

写真 10 染色体分析

口腔領域ではオルソパントモ写真にて，上下顎骨内に 16本の歯牙様不透過像を認めた。 上䫇では右側に 4 本, 左 側に 6 本の埋伏雪様不透過像がみられ，それらが互いに
重なり合っているため歯牙の同定は困難であるが，その 形態と大きさから, 永久歯は $3 \mid 1346$ の 5 本が埋伏し, 他の 5 本は過剩埋伏歯であろらと推察された。下顎で 


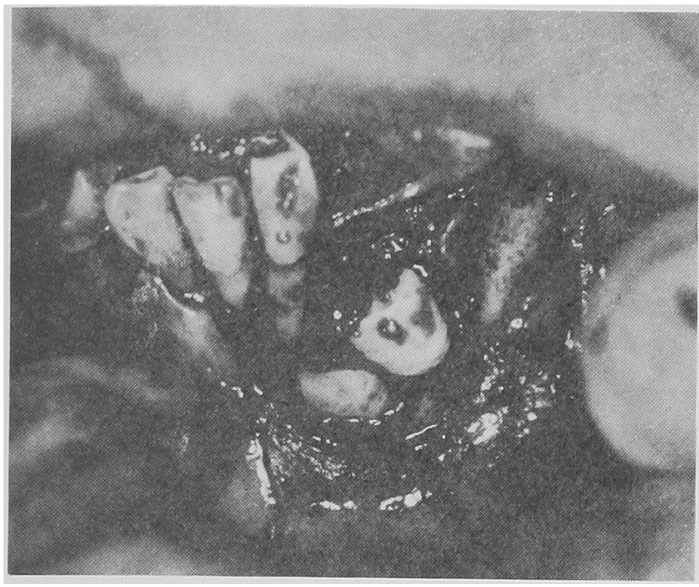

写真 11 手待時所見

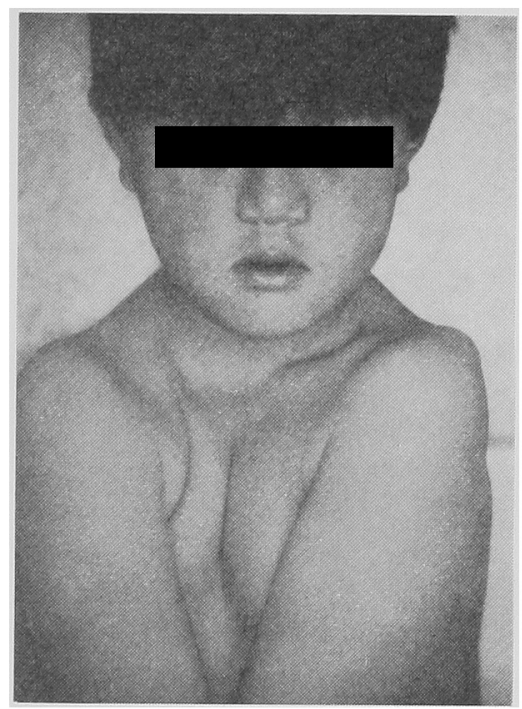

写真 12 正 貌

は，右側飞 $\overline{83}$ ，左側飞 $\sqrt{3458}$ と思われる不透過像が 観察され， 過像を認めた，上䫇洞はほぼ左右対称であるが発育が悪 く，歯槽笑起よりもかなり上方に位置し狭小認められ た，下罘角は鈍角で丸味を帯び，下顎枝はその前後幅径 が小さく細く認められた。 また，筋突起も細く発育不全 を思わせた（写真 6，図 2）。

(2) 胸 部

助骨の 走向はやや急峻で, 鈎鎬状の胸郭を 呈してい た. また，両鎖骨の胸骨端および看峰端約 $1 / 4$ 部に部分 的欠損を認めた（写真 7).

(3) 骨 盤

両側仙腸関節の軽度の離開, 大腿骨頸の短縮, および 骨盤腔の㪎小が認められた（写真 8).

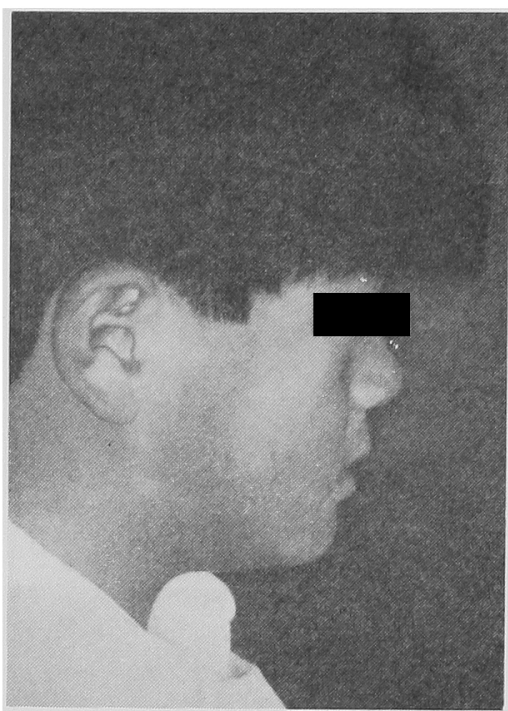

写真 13 溉 貌

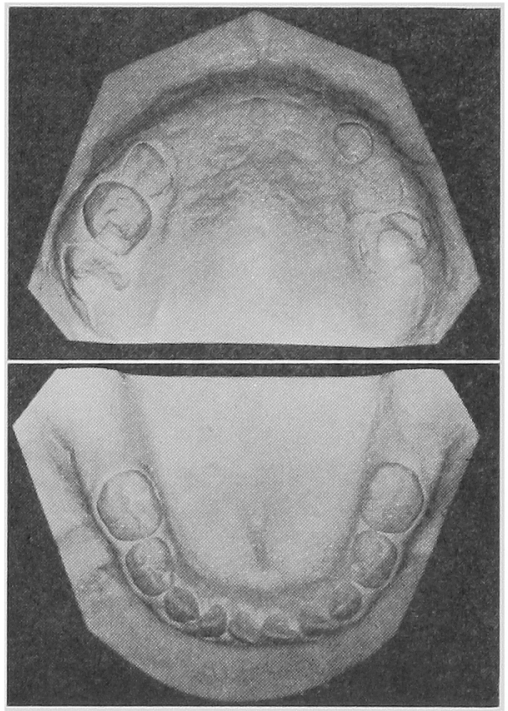

写真 14 上下䫇迷列模型

(4) 手, 足部

手指骨，足趾骨に異常所見は認められなかった（写真 9).

臨床検査および染色体検查：表1，2 亿示すように， クレアチンは $1.09 \mathrm{mg} / \mathrm{d} l$ とやや高值を示し，カルシウ ムと無機リンはそれぞれ $7.8 \mathrm{mg} / \mathrm{d} l, 1.6 \mathrm{mg} / \mathrm{d} l$ とやや 低值を示した以外には特に異常は認められなかった（表 1，2）。 また，静脈血より採取した白血球を分離培荃し 染色体検查を行ったが，その数と形態に異常は認めなか った (写真10).

処置および経過：患者の年歯，希望等を考虑して，保 


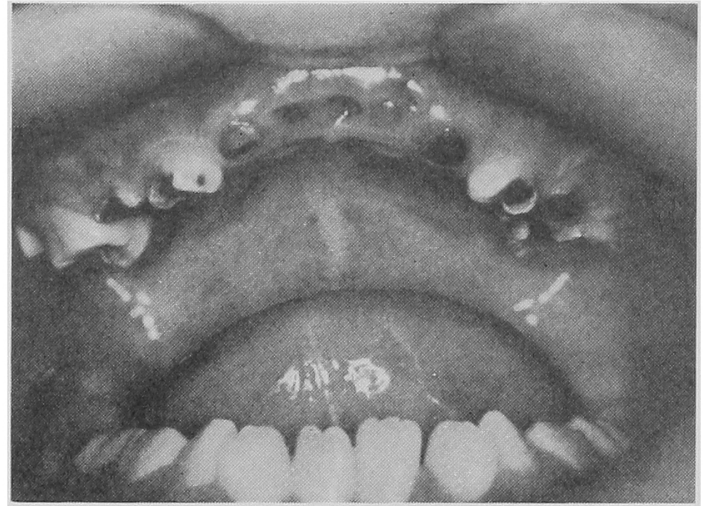

写真 15 口腔内所見
存困難な歯牙を抜去後，欠損部には局部床義菌を作製し 咀嚼機能の改善をはかることとした，以下に処置経過を 示す。

(1) 舌尖部腫瘍切除.病理組織診断は線維腫であった。

(2) 保存不可能な $\frac{76 \mid}{\mid 7}$ を拔齿.

(3) 両側下顎埋伏智歯を抜崡.

(4) 来院動機となった下顎骨骨膜炎の原因菌と考只ら れる $\longdiv { 1 3 4 }$ を拔歯。 X線所見では厉の歯冠周团に震胞 様透過像がみられたが，手術所見では一層の結合織が歯 冠を被っているのみで，露胞形成の所見は認められなか った（写真11）。

術後の治洕経過は良好で, 健常者と比較してもほぼ同 様であった，その後，满玲歯の保存的処置，および欠損

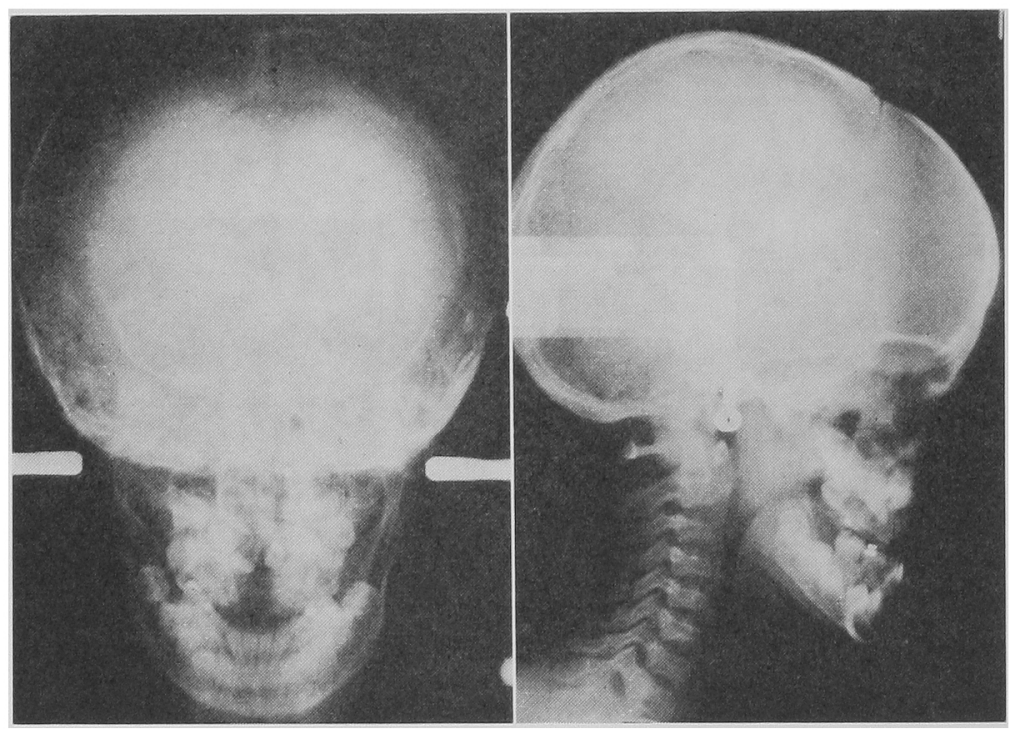

写真 16 頭部 $X$ 線写真

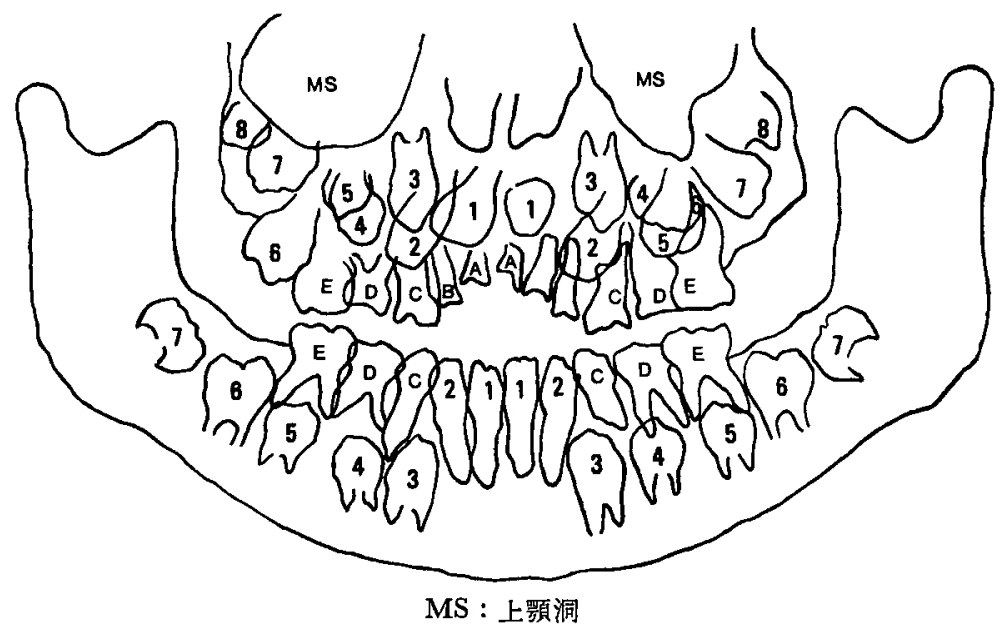

図 3 写真17の模式図 


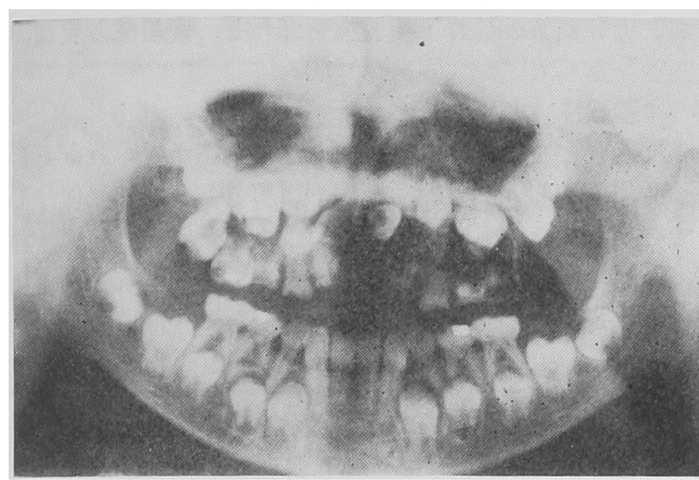

写真 17 オルソパントモ写真

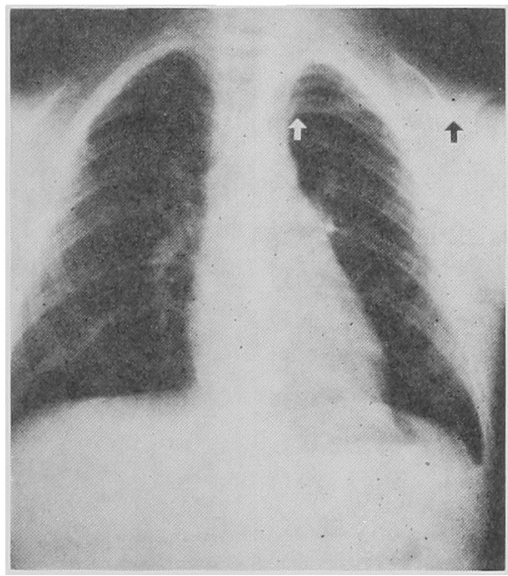

写真 18 胸部X線写真

右鎖骨の全部欠損と左銷骨の内外側端欠損（矢印）

部の補綴的処置を行い現在に至るが，咀礵機能は改善さ れ患者の満足を得ている，また，残存している埋伏崡に ついては経過観察中である。

症例 2

患 者：【10歳 男性.（症例 1 の第 2 子）

初診：昭和58年 3 月 $\square$.

既往歴：母親（症例 1）の言によれば，妊娠中に等に 異常なく経過したが狭骨盤のため帝王切開により出生し た，生下時体重は約 $3,000 \mathrm{~g}$ て，その後特記すべき既往 疾患はなく現在に至っている，乳歯の萠出時期は平均よ りるやや早い方で異常はなかったが，永久歯萌出期にな っても下䫇前歯部を除いて，その荫出は認められなかっ た.

現 症：身長 $131 \mathrm{~cm}$, 体重 $32 \mathrm{~kg}$ で，体格は小柄て あるが栄着状態は良好で，運動障害，知能障害は認めら れなかった，また，母親と同様，両側の眉を苦痛なく前 方で接近させることができるが，心肺等に異常は認めな かった（写真12）.

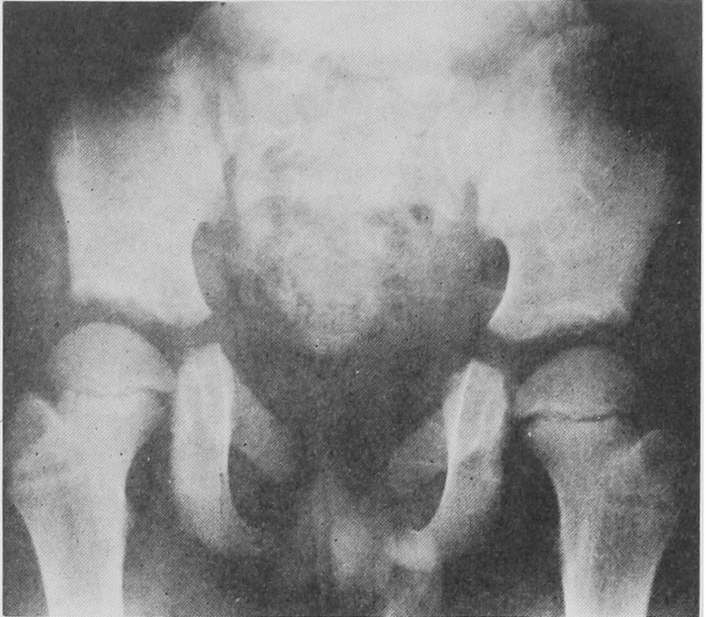

写真 19 骨盤X線写真
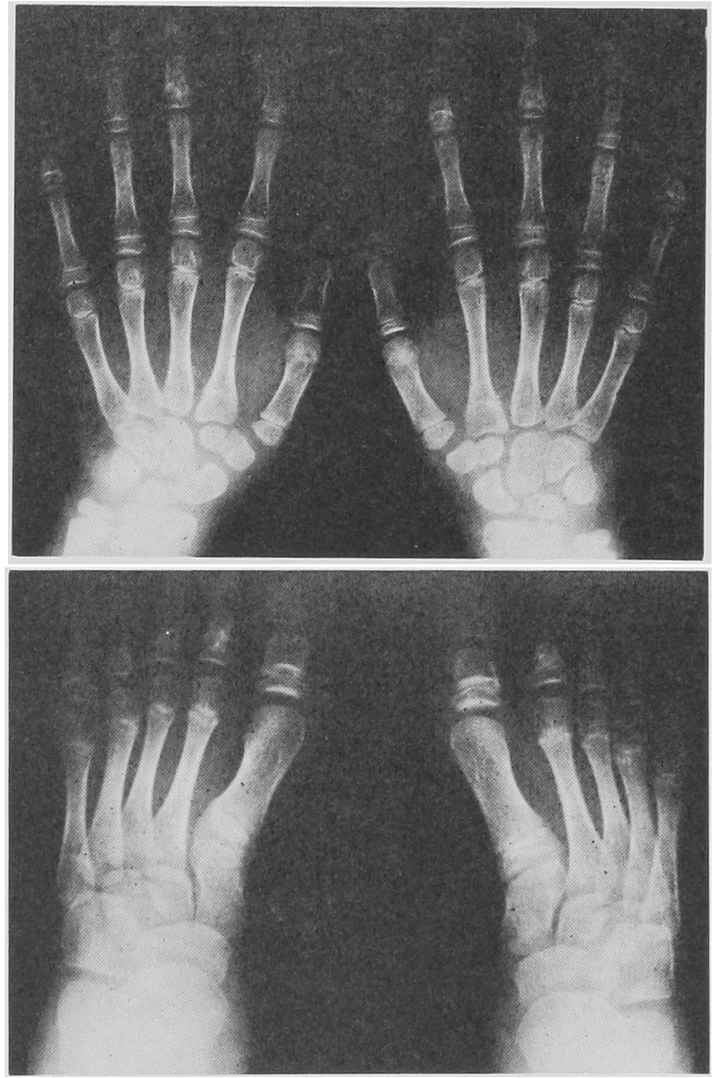

写真 20 手，足のX線写真

顔貌は左右対称で顔色は良好である，鼻根部の発育は やや不良で, 左右内眼角間はやや広く認められた。側貌 は直線型で中顔面の劣成長を思わせた。また，頭頂部を 触䧐すると柔らかく，大泉門の開存を思わせた（写真 
13).

口腔内は，左側上䫚前宷部に過鄱乳側乱歯と思われる 残根を認め，それを含め17本の乳歯と5本の永久歯がみ られた， B A $\mid \mathrm{AB}$ は は残根状態で晚期残存していた，永 久歯は， $\overline{21 \mid 12}$ の完全萌出と6 6 の半萌出を認めるのみ で， $\frac{21 \mid 126}{6 \mid 6}$ は患者の年龄からすると明らかに萌出達 延の状態で，歯肉の触診によっても歯牙による膨隆を触 知できなかた。腔粘膜は，舌，口蓋，頉粘膜，橉肉 等に特記すべき所見は認められなかった（写真14，15）。

\section{$\mathbf{X}$ 線所見 :}

（1）頭部およびロ腔領域

脳頭蓋は顔面頭蓋に比較して大きく，矢状縫合，冠状 縫合の一部，およびそれらが交叉する部に骨形成不全と 思われる 透過像を認め，大泉門の開存がみられた。

表 3 血液一般検查

\begin{tabular}{lr|cr}
\hline 血色素量 & $14.8 \mathrm{~g} / \mathrm{d} l$ & 白血球像 & \\
赤血球数 & $551 \times 10^{4}$ & $\mathrm{St}$ & $1 \%$ \\
白血球数 & 6,000 & $\mathrm{Seg}$ & $41 \%$ \\
$\sim$ マトクリット值 & $43.9 \%$ & $\mathrm{E}$ & $5 \%$ \\
血小板数 & $29.1 \times 10^{4}$ & $\mathrm{~B}$ & $0 \%$ \\
網赤血球数 & $7 \% 0$ & $\mathrm{M}$ & $3 \%$ \\
血液比重 & 1.057 & $\mathrm{Ly}$ & $50 \%$ \\
血液型 & $\mathrm{A}$ & & \\
出血時間 & 2 分 0秒 & & \\
凝固時間 & 9 分30秒 & & \\
\hline
\end{tabular}

た，上顎の劣成長と下顎前突を思わせ，硬組織側貌は陌 凹型を呈していた（写真16）.

口腔領域ではオルソパントモ写真にて， BA|A B の 晚期残存と左側上顎過剩乳側切齿の牫根がみられ，その 上方に 21112 が雬軸を捻転や傾斜させた状態て埋伏し ていた，その後方には，右側では 543|，左側では|3456 と思われる不透過像が互いに重複してみられ判然としな

表 4 血清生化学検查

\begin{tabular}{|c|c|c|c|}
\hline \multicolumn{2}{|c|}{$\begin{array}{l}\text { 血滑総タンバク } 7.3 \mathrm{~g} / \mathrm{d} l \\
\text { 血清タンバク分画 }\end{array}$} & $\begin{array}{l}\text { 棇コレス } \\
\text { テロール }\end{array}$ & $198 \mathrm{mg} / \mathrm{d} l$ \\
\hline アルブミン & $65.4 \%$ & トリグリ & $43 \mathrm{mg} / \mathrm{d} l$ \\
\hline グロブリン & $3.5 \%$ & $\beta$-リポ蛋白 & $480 \mathrm{mg} / \mathrm{d} l$ \\
\hline & $10.2 \%$ & 血清鉄 & $100 \mu \mathrm{g} / \mathrm{d} l$ \\
\hline & $8.8 \%$ & $\gamma-\mathrm{GTP}$ & $15 \mathrm{mU} / \mathrm{ml}$ \\
\hline & $11.8 \%$ & クレアチン & $1.04 \mathrm{mg} / \mathrm{d} l$ \\
\hline$A G$ 比 & 1.89 & 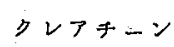 & $0.56 \mathrm{mg} / \mathrm{dl}$ \\
\hline 血清黄宣指数 & 4 & BUN & $15 \mathrm{mg} / \mathrm{d} l$ \\
\hline $\begin{array}{l}\text { 血清総 } \\
\text { ビリルビン }\end{array}$ & $0.30 \mathrm{mg} / \mathrm{d} l$ & 尿 酸 & $3.7 \mathrm{mg} / \mathrm{d} l$ \\
\hline ALP & $10.1 \mathrm{KAU}$ & $\mathrm{Na}$ & $141 \mathrm{mEq} / l$ \\
\hline GOT & $21 \mathrm{KU}$ & $\mathbf{K}$ & $4.3 \mathrm{mEq} / l$ \\
\hline GPT & $11 \mathrm{KU}$ & $\mathrm{Cl}$ & $105.8 \mathrm{mEq} / \mathrm{l}$ \\
\hline ChE & 1. $40 \Delta \mathrm{pH}$ & $\mathrm{Ca}$ & $9.2 \mathrm{mg} / \mathrm{d} l$ \\
\hline $\mathrm{LDH}$ & 352 WU & $\mathbf{P}$ & $3.6 \mathrm{mg} / \mathrm{d} l$ \\
\hline LAP & 174 GRU & & \\
\hline アミラーゼ & $93 \mathrm{SU}$ & & \\
\hline
\end{tabular}
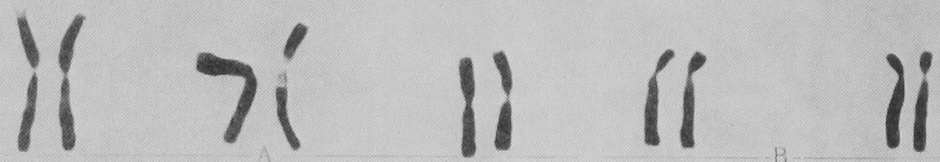

II
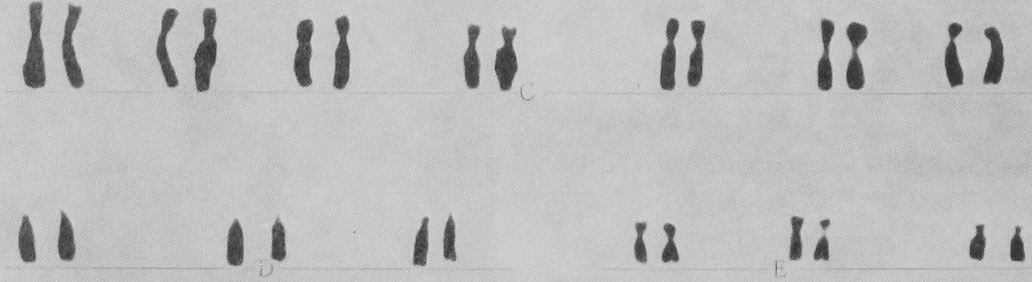

is

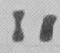

$+4$
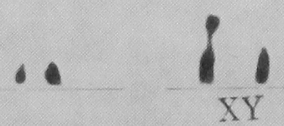

写真 21 染色体分析 
表 5 著者らが追加涉編した報告例と自験例

\begin{tabular}{|c|c|c|c|c|c|c|c|c|c|c|}
\hline \multirow{2}{*}{ 報 告 者 } & \multirow{2}{*}{ 報告年 } & \multirow{2}{*}{ 年龄 } & \multirow{2}{*}{ 性 } & \multirow{2}{*}{ 兑伝 } & \multirow{2}{*}{ 䠝骨欠損 } & \multicolumn{3}{|c|}{ 頭 蓋異常 } & \multirow{2}{*}{$\begin{array}{l}\text { 口腔領域の } \\
\text { 異常所見 }\end{array}$} & \multirow{2}{*}{ その他の異常所見 } \\
\hline & & & & & & $\begin{array}{l}\text { 泉門 } \\
\text { 開存 }\end{array}$ & $\begin{array}{l}\text { 䋖合 } \\
\text { 離開 }\end{array}$ & \begin{tabular}{|l|l|} 
腢間 \\
骨 \\
\end{tabular} & & \\
\hline 1. 永井春三12) & 1958 & 7 & 男 & $(-)$ & 両外側 & $(+)$ & $(+)$ & $(+)$ & 永久料萌出遅延 & $\begin{array}{l}\text { 恥骨結合離開 } \\
\text { 四肢骨 }\end{array}$ \\
\hline 2. 木村光孝 ${ }^{13)}$ & 1972 & & 女 & 母 & 両側仮関節 & $(+)$ & & & 埋状蒾, 過剩茵 & \\
\hline 3. 木村光孝 ${ }^{13)}$ & 1972 & 11 & 男 & 子 & 両外㑡 $1 / 3$ & $(+)$ & $(+)$ & $(-)$ & $\begin{array}{l}\text { 乳菌晚存, 埋伏菌 } \\
\text { 過剩菌, 高口蓋 }\end{array}$ & \\
\hline 4. 園山 昇 ${ }^{14)}$ & 1977 & 25 & 女 & $(-)$ & 両内側 & $(-)$ & $(+)$ & $(-)$ & $\begin{array}{l}\text { 反対咬合, 埋伏料 } \\
\text { 過剩菌 }\end{array}$ & $\begin{array}{l}\text { 恥骨結合粗 } \\
\text { 足骨短小 }\end{array}$ \\
\hline 5. 西村 章 ${ }^{15)}$ & 1977 & 13 & 女 & $(-)$ & 両外側 $2 / 3$ & $(+)$ & $(+)$ & $(+)$ & 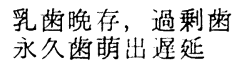 & $\begin{array}{l}\text { 恥骨結合離開 } \\
\text { 仙腸関節開大 }\end{array}$ \\
\hline 6. 本田武司 ${ }^{33)}$ & 1977 & 23 & 女 & $(-)$ & $\begin{array}{l}\text { 右全部 } \\
\text { 左形成不全 }\end{array}$ & $(-)$ & $(-)$ & $(-)$ & $\begin{array}{l}\text { 単菌残存, 反対咬 } \\
\text { 合, 埋伏送, 過剩菡 }\end{array}$ & 長管骨がやや紐い \\
\hline 7. 西村 修 ${ }^{16)}$ & 1979 & 16 & 女 & $(-)$ & 両側部分的 & $(+)$ & $(+)$ & & 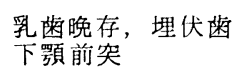 & 恥骨結合異常 \\
\hline 8. 田中 勉 ${ }^{17)}$ & 1979 & 5 & 女 & $(-)$ & $(+)$ & $(+)$ & $(+)$ & & $\begin{array}{l}\text { 関節突起形成不全 } \\
\text { 下顎正中旋合不全 }\end{array}$ & \\
\hline 9. 田中 勉17) & 1979 & 2 & 女 & $(-)$ & $(+)$ & $(+)$ & $(+)$ & & & \\
\hline 10. 中澤敏旦 ${ }^{18)}$ & 1979 & 18 & 男 & $(-)$ & 両外側 & $(+)$ & $(+)$ & & $\begin{array}{l}\text { 乳菌晚存, 埋伏䉿 } \\
\text { 反対咬合 }\end{array}$ & $\begin{array}{l}\text { 狭骨盤 } \\
\text { 恥骨結合離開 }\end{array}$ \\
\hline 11. 田中勇三19) & 1980 & 6 & 男 & $(-)$ & 部分欠損 & & $(+)$ & $(+)$ & & $\begin{array}{l}\text { 狭骨盤, 脊椎破裂 } \\
\text { 恥骨結合離開 }\end{array}$ \\
\hline 12. 見崎 徽 ${ }^{20)}$ & 1980 & 31 & 男 & $(-)$ & $(+)$ & & $(+)$ & & $\begin{array}{l}\text { 下罘前乫, 埋伏菌 } \\
\text { 過剩菌 }\end{array}$ & \\
\hline 13. 野本泰正 ${ }^{21)}$ & 1980 & 12 & 女 & 同胞 & 部分欠損 & $(+)$ & & & & $\begin{array}{l}\text { 狭骨盤 } \\
\text { 恥骨・坐骨形成不全 }\end{array}$ \\
\hline 14. 野本泰正 ${ }^{21)}$ & 1980 & 8 & 女 & & 部分欠損 & $(+)$ & & & & $\begin{array}{l}\text { 狭骨盤 } \\
\text { 恥骨・坐骨形成不全 }\end{array}$ \\
\hline 15. 宮野前建 ${ }^{22)}$ & 1980 & 3 & 男 & 同胞 & & & & & & $\begin{array}{l}\text { 尿道下裂, 鎖肛 } \\
\text { 肛門位置常 }\end{array}$ \\
\hline 16. 宮野前建 ${ }^{22)}$ & 1980 & 1 & 女 & & & & & & & 両眼隔離 \\
\hline 17. 梶 隆一9) & 1981 & 16 & 男 & $(-)$ & $\begin{array}{l}\text { 右外側 } 1 / 3 \\
\text { 左部分欠損 }\end{array}$ & $(+)$ & $(+)$ & & $\begin{array}{l}\text { 乳隩晚存, 高口蓋 } \\
\text { 反対咬合 }\end{array}$ & $\begin{array}{l}\text { 仙腸関節開大 } \\
\text { 恥,骨結合離開 }\end{array}$ \\
\hline 18. 厇瀬永康 ${ }^{23)}$ & 1981 & 10 & 男 & $(-)$ & 両外㑡 & $(-)$ & $(+)$ & $(-)$ & $\begin{array}{l}\text { 乳菌晚存, 高口蓋 } \\
\text { 埋伏米, 反対咬 }\end{array}$ & 骨盤発育不全 \\
\hline 19. 許斐博史 ${ }^{24)}$ & 1981 & 32 & 女 & 丹: & 両㑡中央 & $(+)$ & $(+)$ & $(+)$ & 埋伏歯 & 脊椎破裂 \\
\hline 20. 許斐博史 ${ }^{24)}$ & 1981 & $\begin{array}{c}4 \\
M\end{array}$ & 女 & 子 & $\begin{array}{l}\text { 右全部 } \\
\text { 左外側 } 1 / 2\end{array}$ & $(+)$ & & $(+)$ & & $\begin{array}{l}\text { 脊椎破裂 } \\
\text { 就峃枝形成不全 }\end{array}$ \\
\hline 21. 山川義亮 25$)$ & 1981 & 40 & 男 & 父 & 直線的 & & & & $\begin{array}{l}\text { 乳菌残存 } \\
\text { 埋伏困 }\end{array}$ & \\
\hline 22. 山川義亮 ${ }^{25)}$ & 1981 & 9 & 男 & 子 & 直線的 & & & & $\begin{array}{l}\text { 乳畨残存 } \\
\text { 永久米萌出避延 }\end{array}$ & \\
\hline 23. 泣川幹男 ${ }^{26)}$ & 1981 & 14 & 女 & $(+)$ & 両側全部 & $(+)$ & $(+)$ & & 埋伏菌 & $\begin{array}{l}\text { 狭骨盤, 外反股 } \\
\text { 骨盤形成不全 }\end{array}$ \\
\hline 24. 深沢裕交 ${ }^{27)}$ & 1982 & 11 & 男 & $(-)$ & $\begin{array}{l}\text { 両側 } \cdot \text { 内外 } \\
\text { 側 }\end{array}$ & $(-)$ & $(-)$ & $(-)$ & $\begin{array}{l}\text { 反対咬合, 埋伏過 } \\
\text { 剩陶 }\end{array}$ & $\begin{array}{l}\text { 恥骨結合離開, } \\
\text { 仙晹関節㗺開 }\end{array}$ \\
\hline 25. 渡辺 熙28) & 1982 & 49 & 男 & $(+)$ & 両外側 & $(+)$ & $(+)$ & $(-)$ & 発育不全 & 潜在性 2 分脊椎 \\
\hline 26. 渡㲽 隐 28$)$ & 1982 & 16 & 男 & $(-)$ & 両側全部 & $(+)$ & $(+)$ & $(+)$ & & 脊椎変形 \\
\hline 27. 渡辺 哭 28) & 1982 & $\begin{array}{l}10 \\
\mathbf{M}\end{array}$ & 男 & $(-)$ & 両外㑡 & $(+)$ & $(+)$ & $(-)$ & & \\
\hline 28. 渡部 健 $^{29)}$ & 1982 & 43 & 男 & 父 & 両外側 & $(+)$ & $(+)$ & $(+)$ & 埋伏㐘 & $\begin{array}{l}\text { 曶骨形成不全 } \\
\text { 節骨形成不全 }\end{array}$ \\
\hline 29. 渡部 健 ${ }^{29)}$ & 1982 & 9 & 男 & 子 & 両側全部 & $(+)$ & $(+)$ & $(+)$ & $\begin{array}{l}\text { 孚歯晚存, 埋伏楼 } \\
\text { 反対咬合 }\end{array}$ & $\begin{array}{l}\text { 腸骨形成不全 } \\
\text { 内反股 }\end{array}$ \\
\hline
\end{tabular}


（表 5 つつ゚き）

\begin{tabular}{|c|c|c|c|c|c|c|c|c|c|c|c|c|}
\hline \multirow{2}{*}{\multicolumn{3}{|c|}{ 報 告 者 }} & \multirow[b]{2}{*}{ 報告年 } & \multirow[b]{2}{*}{ 年齢 } & \multirow[b]{2}{*}{ 性 } & \multirow[b]{2}{*}{ 遣伝 } & \multirow[b]{2}{*}{ 轵骨欠損 } & \multicolumn{3}{|c|}{ 頭蓋異 常 } & \multirow{2}{*}{$\begin{array}{l}\text { 口腔領域の } \\
\text { 異常所見 }\end{array}$} & \multirow[b]{2}{*}{ その他の異常所見 } \\
\hline & & & & & & & & $\begin{array}{l}\text { 泉門 } \\
\text { 㯺存 }\end{array}$ & \begin{tabular}{|l|} 
䋖合 \\
離開
\end{tabular} & \begin{tabular}{l|} 
插間 \\
骨
\end{tabular} & & \\
\hline 30. & 楊 & 栄展 30 ) & 1983 & 53 & 男 & 父 & 両側全部 & $(-)$ & $(+)$ & $(+)$ & $\begin{array}{l}\text { 高口荎, 埋伏歯, } \\
\text { 反対咬合 }\end{array}$ & \\
\hline & 楊 & 栄展 30 ) & 1983 & 21 & 女 & 子 & 两側全部 & $(+)$ & $(+)$ & $(+)$ & $\begin{array}{l}\text { 乳歯残存, 埋伏曾 } \\
\text { 過剩茵, 反対咬合 }\end{array}$ & $\begin{array}{l}\text { 狭骨盤，末節骨形 } \\
\text { 成不全 }\end{array}$ \\
\hline \multicolumn{3}{|c|}{ 2. 水野智之 ${ }^{31)}$} & 1983 & 13 & 男 & $(-)$ & 両外側 $2 / 3$ & $(+)$ & $(+)$ & & $\begin{array}{l}\text { 下顎前突, 乳茵晚 } \\
\text { 存, 口蓋正中の慣 }\end{array}$ & 指趾末節短縮 \\
\hline \multicolumn{3}{|c|}{ 3. 金沢洽樹 ${ }^{32)}$} & 1984 & 11 & 男 & \multirow{2}{*}{ 同胞 } & 両外側 & $(+)$ & \multicolumn{2}{|l|}{$(+)$} & $\begin{array}{l}\text { 埋伏歯, 下顎前突 } \\
\text { 高口蓋, 正中の溝 }\end{array}$ & $\begin{array}{l}\text { 仙腸関節, 恥骨結合 } \\
\text { 哆開 }\end{array}$ \\
\hline 34. & \multicolumn{2}{|c|}{ ． 金沢治樹 ${ }^{32)}$} & 1984 & 14 & 女 & & 両外側 & $(+)$ & \multirow[b]{2}{*}{(} & \multirow[b]{2}{*}{$(+)$} & & 狭骨盤 \\
\hline 35. & \multicolumn{2}{|c|}{ 著者ら } & 1984 & 39 & 女 & 母 & $\begin{array}{l}\text { 西側 · } \\
\text { 内外側 }\end{array}$ & $(-)$ & & & $\begin{array}{l}\text { 埋伏菌, 過鄱茵 } \\
\text { 口蓋正中の溝 }\end{array}$ & 仙腸関節離開 \\
\hline \multicolumn{3}{|c|}{ 6. 著者ら } & 1984 & 10 & 男 & 子 & $\begin{array}{l}\text { 右全部 } \\
\text { 左外側 }\end{array}$ & $(+)$ & $(+)$ & $(-)$ & $\begin{array}{l}\text { 乳菌晚存, 永久蒌 } \\
\text { 萌出遅延 }\end{array}$ & 骨盤形成不全 \\
\hline
\end{tabular}

いが，過鄱雨は認められないよらであった。下顎では， 永久歯は $\overline{21 \mid 12}$ の久萌出し, $\overline{6 \mid 6}$ は埋伏し萌出遅延 の状態であるが，他の犬歯，小臼歯，第 2 大臼歯を含め 歯芽の位置に異常は認められなかった（写真17, 図了）。

(2) 胸 部

肋骨の走向は母親と同様にやや急峻で，鈎鐘状の胸郭 を呈していた。 また，右鎖骨の完全欠如と左鎖骨の屃峰 端約 $1 / 5$ 部の部分欠損が認められた（写真18）.

（3）骨 盤

骨盤の形成は全体に遅延して括り，腸骨，坐骨，恥骨 間の化骨遅延, 左右恥骨結合面の離開, 拉上び寛骨臼の 形成不全が認められた（写真19）。

(4) 手, 足部

手，足の骨に異常は認められず，骨年路もほぼ正常で あった（写真20).

臨床検查および染色体検査：表 3，4 亿示すように異 常値は認められなかった。 また，静脈血より採取した白 血球を分離培養し染色体検査を行ったが，その形態と数 に異常は認められなかった（表 3，4，写真21）.

処置および経過：患者の年跲，母親の希望を考慮し， 本学矯正科の協力を得て埋伏した永久歯を可及的に萌出 させ，口腔領域の番美的，機能的改善をはかることとし た。現在のところ， C B A |A B と左上䋶過剩乳側切歯 を抜去後， $321 \mid$ を開空しェラスティクスによる旁引誘 動を施行中である。

\section{考察}

鎖骨頭蓋異骨症は, 鎖骨および頭蓋骨の形成不全, 歯 の発育不全, および遗伝性を主徵とする先天性の症候群 で，1898年, Marie and Saintonによってその概念が確 立された2). その後, 欧米においては600 例以上が報告
されている3,4)。本邦に扣いては，下里ら (1967) ${ }^{10)}$ か30 例, 渡辺ら (1972 $)^{11)}$ か 40 例, 有瀧ら $(1976)^{5)}$ か 89 例, 亀 谷ら $(1980)^{8)}$ が117例の本邦報告例を涉椫している.著者 らはこれら先人の業績を基礎に，亀谷ら ${ }^{8)}$ の報告にあら たに33例, 12 32)を追加涉編した。ささらに，当教室の本田 $5^{33}$ の既報告例 1 例と今回の自験例 2 例を加之て, 本邦 では少なくとも153 例が報告されている。表 5 亿著者ら が追加渉㧩した症例と自験例 3 例を示した（表 5 ).

本症は先天性の症候群であるにもかかわらず，日常生 活に打いて機能障害となる要素が少ないために，その発 見は遅れる場合も多く，報告例の年龄は 2 か月から50歳 以上にまで及んでいる，発見は，全身的な発育不良，頭 蓋変形, 反対咬合, 永久雨の萌出遅延などの主訴をもっ て，小児科，整形外科，歯科などを受診した際，あるい は検診時に偶然発見される場合が多いようで，とりわけ 近年では, パノラマX線写真の普及によって函科, 口腔 外科領域で発見される機会も多くなったようである，自 験例の症例 1 は3 歳女性で, 埋伏歯への感染によって 骨膜炎を発症し，当科を受診し発見されたものであり， その家族歴より第 2 子に永久歯の萌出遅延があることが わかり, 精査の結果症例 2 が判明した.

性別発現頻度は，欧米，本邦に执いても男女間に差は ないと述べられている5,34) 著者らが集めた 153 例です， 男性81例，女性70例，記載なし 2 例で，ほとんと性差は ないと思われる。

本症の原因は未だ不明であるが，何等かの原因により 全身的膜内化骨不全の病態を示すといわれ，特に頭蓋 骨, 䈐椎, 恥骨結合などの正中線に沿らものが多いとさ れている311.

頭蓋骨の異常は, 泉門の開存, 縫合部の化骨不全, 縫 合部周囲の插間骨の存在, 顔面頭蓋に比較して脳頭蓋か; 大きいなどの所見が述べられているが，これらの所見は 
表 6 本邦に打ける家族的発症例

\begin{tabular}{|c|c|c|c|c|c|c|c|}
\hline 報 告 者 & 報告年 & 年 齢 & 性 & 遗伝 & 鎖骨欠損 & 頭蓋異常 & $\begin{array}{l}\text { 口䀵領域 } \\
\text { の異常 }\end{array}$ \\
\hline 1. 桐田 良人 & 1954 & 58 & 男 & 父 & $(+)$ & & \\
\hline 2. 桐田 良人 & 1954 & 14 & 男 & 子 & $(+)$ & & \\
\hline 3. 後 藤 澄 & 1960 & 6 & 女 & + + & $(+)$ & $(+)$ & \\
\hline 4. 山谷 勇三 & 1965 & 42 & 男 & 父 & & $(+)$ & $(+)$ \\
\hline 5. 山谷 勇三 & 1965 & 6 & 男 & 子 & & $(+)$ & $(+)$ \\
\hline 6. 真角 昭吾 & 1965 & 4 & 女 & + 父, 兄 & $(+)$ & $(+)$ & \\
\hline 7. 天 野 曄 & 1965 & 24 & 女 & 母 & & & \\
\hline 8. 天野 瞱 & 1965 & $10 \mathrm{M}$ & 男 & 子 & $(+)$ & $(+)$ & \\
\hline 9. 水本 潔 & 1967 & 30 & 男 & 父 & & & \\
\hline 10. 水本 潔 & 1967 & 4 & 女 & 子 & & & \\
\hline 11. 小池 宣之 ${ }^{46)}$ & 1968 & 2 & 男 & + 母 & $(+)$ & $(+)$ & $(+)$ \\
\hline 12. 中川 俊丈 & 1969 & 55 & 女 & 祖母 & & & \\
\hline 13. 中川 俊丈 & 1969 & 26 & 女 & 母 & & & \\
\hline 14. 中川 俊丈 & 1969 & $6 \mathrm{M}$ & 男 & 子 & & & \\
\hline 15. 石井 引一 & 1969 & 14 & 女 & 十母, 同胞 2 & & & \\
\hline 16. 楖 沢＼cjkstart瀜 36 ) & 1969 & 47 & 男 & 父 & $(+)$ & $(+)$ & $(+)$ \\
\hline 17. 柳 沢 融年6) & 1969 & 15 & 女 & 子 & $(+)$ & $(+)$ & $(+)$ \\
\hline 18. 楖 沢＼cjkstart融 ${ }^{36)}$ & 1969 & 10 & 男 & 子 & $(+)$ & $(+)$ & $(+)$ \\
\hline 19. 宮城＼cjkstart克史 & 1971 & 34 & 女 & 母 & $(+)$ & & \\
\hline 20. 宮城 克史 & 1971 & 7 & 女 & 子 & $(+)$ & & $(+)$ \\
\hline 21. 水田 隆三 ${ }^{47)}$ & 1971 & 30 & 男 & 父 & $(+)$ & $(+)$ & \\
\hline 22. 水田 隆三 ${ }^{47)}$ & 1971 & 3 & 男 & 子 & $(+)$ & $(+)$ & \\
\hline 23. 水田 隆三 ${ }^{74)}$ & 1971 & $4 \mathrm{M}$ & 女 & 子 & $(+)$ & $(+)$ & \\
\hline 24. 水田 隆三 ${ }^{47)}$ & 1971 & 37 & 男 & 父 & $(+)$ & $(+)$ & \\
\hline 25. 水田 隆三 ${ }^{47)}$ & 1971 & 4 & 女 & 子 & $(+)$ & $(+)$ & \\
\hline 26. 渡辺 信彦 ${ }^{11)}$ & 1972 & 57 & 女 & 祖母 & $(+)$ & $(+)$ & \\
\hline 27. 渡辺 信彦 ${ }^{11)}$ & 1972 & 33 & 男 & 父 & $(+)$ & $(+)$ & $(+)$ \\
\hline 28. 渡辺 信彦 ${ }^{11)}$ & 1972 & 2 & 女 & 子 & $(+)$ & $(+)$ & \\
\hline 29. 木村 光孝 ${ }^{13)}$ & 1972 & & 女 & 母 & $(+)$ & $(+)$ & $(+)$ \\
\hline 30. 木村 光孝 ${ }^{13)}$ & 1972 & 11 & 男 & 子 & $(+)$ & $(+)$ & $(+)$ \\
\hline 31. 北川 敏夫 ${ }^{48)}$ & 1973 & 51 & 男 & 父 & $(+)$ & & \\
\hline 32. 北川 敏夫 ${ }^{48)}$ & 1973 & 10 & 女 & 子 & $(+)$ & & $(+)$ \\
\hline 33． 有瀧世界爺5) & 1975 & 32 & 女 & 母: & $(+)$ & $(+)$ & $(+)$ \\
\hline 34． 有澈世界莭 ${ }^{5)}$ & 1975 & 2 & 女 & 子 & $(+)$ & $(+)$ & \\
\hline 35. 倉科＼cjkstart憲治37) & 1978 & 43 & 女 & 母 & $(-)$ & $(+)$ & $(+)$ \\
\hline 36． 倉科 慧治 ${ }^{37)}$ & 1978 & 21 & 男 & 子 & $(+)$ & $(+)$ & $(+)$ \\
\hline 37．倉科＼cjkstart憲治37) & 1978 & 16 & 女 & 子 & $(+)$ & $(+)$ & $(+)$ \\
\hline 38． 倉科＼cjkstart憲治37) & 1978 & 18 & 男 & 子 & & $(+)$ & $(+)$ \\
\hline 39. 許斐 博史 ${ }^{24)}$ & 1981 & 32 & 女 & 母 & $(+)$ & $(+)$ & $(+)$ \\
\hline 40. 許斐 博史 ${ }^{24)}$ & 1981 & $4 \mathrm{M}$ & 女 & 子 & $(+)$ & $(+)$ & \\
\hline 41. 山川＼cjkstart義亮 ${ }^{25)}$ & 1981 & 40 & 男 & 父 & $(+)$ & & $(+)$ \\
\hline 42. 山川＼cjkstart義亮 ${ }^{25)}$ & 1981 & 9 & 男 & 子 & $(+)$ & & $(+)$ \\
\hline 43. 滝川＼cjkstart幹男26) & 1981 & 14 & 女 & 十父 & $(+)$ & $(+)$ & $(+)$ \\
\hline 44. 渡辺 熙 28$)$ & 1982 & 49 & 男 & $\begin{array}{l}\text { 十祖母, 舟, } \\
\text { 兄, 妹, 子 } 2 \text { 人 }\end{array}$ & $(+)$ & $(+)$ & $(+)$ \\
\hline
\end{tabular}


（表6 つづき）

\begin{tabular}{|c|c|c|c|c|c|c|c|c|c|c|}
\hline 報 & 告 & 者 & 報告年 & 年 齢 & 性 & & 伝 & 鎖骨欠損 & 頭蓋異常 & $\begin{array}{l}\text { 口腔領域 } \\
\text { の異常 }\end{array}$ \\
\hline 45. 源 & 度 部 & 健 ${ }^{29)}$ & 1982 & 43 & 男 & 父 & & $(+)$ & $(+)$ & $(t)$ \\
\hline 46. 源 & 度部 & 健 29$)$ & 1982 & 9 & 男 & 子 & & $(t)$ & $(+)$ & $(+)$ \\
\hline 47. 楊 & 昜 栄 & 展 ${ }^{30}$ & 1983 & 53 & 男 & 父 & & $(+)$ & $(+)$ & $(t)$ \\
\hline 48. 楊 & 昜 栄 & 展 30$)$ & 1983 & 21 & 女 & 子 & & $(+)$ & $(+)$ & $(t)$ \\
\hline 49. 著 & 者者ら & & 1984 & 39 & 女 & 母 & & $(+)$ & $(+)$ & $(+)$ \\
\hline 50. 著 & 萻者ら & & 1984 & 10 & 男 & 子 & & $(+)$ & $(+)$ & $(+)$ \\
\hline
\end{tabular}

1 は亀谷ら ${ }^{8)}$ より引用, $3 \sim 10,12 \sim 15,19,20$ は有瀧ら5) より引用

化骨の程度によりさまざまな状態を呈している。たとえ ば，深沢ら ${ }^{27)}$ は頭蓋骨に明瞭な化骨不全を認めなかった 11歳の症例を本症の不全型として報告し，本田 $5^{33}$ (は頭 蓋皮質骨に硬化様所見を認めた23歳の症例を報告してい る。これらとは反対に，持山 ${ }^{35}$ は42歳に，柳沢ら ${ }^{36)}$ は47 歳になっても大泉門の開存がみられた症例を報告してい る. 自験例の症例 1 では大泉門の開存はみられず, 縫合 部の瘾合不全と插間骨を認めたが, 症例 2 では大泉門の 開存と縫合部の瘳合不全を認めた。症例 2 は若年者であ るので，徐々に化骨が進み，縫合部および泉門の間陌は 減少する可能性も考光られ，今後の経過を観察する予定 である。

また，顔面頭蓋を形成する鼻骨，涙骨，上䫇骨，口蓋 骨，下顎骨などにも形成不全による変化が認められる。 すなわち，鼻根部は陷凹して鞍學を呈し，副鼻腔は狭小 で，上顎の劣成長のため下顎前突を呈する場合が多いよ

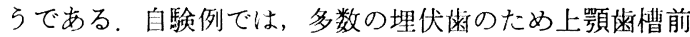
方限界点の設定が困難であったので，七ファロ分析は行 わなかったが，上顎の劣成長，下顎前突，下顎角の開大 などがらかがわれた。下顎骨の形態については，下顎角 は丸く移行的な形態を示し, 下顎切痕は浅く，筋突起，

下顎頭部の発育不全が钼察された。蓋についても，高 口蓋や口蓋の正中に沿って走る溝の存在などが多数報告 されている ${ }^{9,13,14,30)}$ 自験例の症例 1 では, 正中に浅い 溝がみられたが，症例 2 では異常所見は認めなかった。

歯牙の異常も本症の特徵の 1 つで，一般に乳曾の晚期 残存，永久米萌出遅延あるいは埋伏，過剩埋伏曾など が報告されている。しかし，乳雪が埋伏することはな く10)，本来乳菡列に属するとされる大田柬が埋伏するこ とは少ない33,37)よ5である。著者らの症例 2 は10藏であ

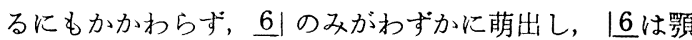
骨の深部に位医し， $\overline{6 \mid 6}$ は末萌出であったことは特筆 すべき所見である。ささらに本例の左側上顎前歯部には，

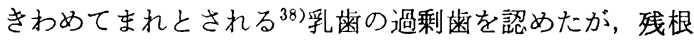
状態であったため本来の乳切歯との鑑別は不可能であっ た。乳歯過剰幽と本症との関係は全く不明であるが，他 に記載をみないものである。
埋伏菊数については, 多いものでは過剰菌も含めて,

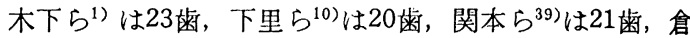

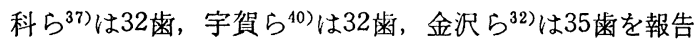
している。埋伏過剩歯単独については，遠藤ら ${ }^{41)}$ は 6 歯, 深沢ら ${ }^{27)}$ は12歯，倉科ら ${ }^{37)}$ は14歯を報告している. 自験例の症例 1 では16本の埋伏崡を認め，その鑑別は困 難であるが, 11本は永久歯で, 残りの 5 本は過剩歯であ ろらと推察された。 また，Hesse ${ }^{42)}$ は本症のほとんとに 深部埋伏歯を有し，これに寱胞の形成をみることがある

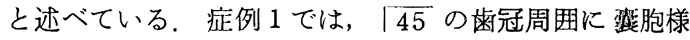
X線透過像を認めたが，手術所見では翼胞はみられず肥

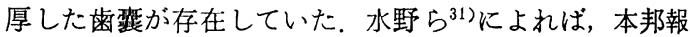
告例のらち翼胞の存在を確認しているのは, 関本ら ${ }^{39)}$, 本橋ら ${ }^{43)}$, 河野ら ${ }^{44)}$ の 3 例にすぎない。

鎖骨の欠損も頭蓋骨の異常と同様に種々の程度に存在 する，有瀧ら5)によれば，鎖骨欠損について記载の明ら かな本邦報告例65例のらち，再側性欠損は58例(89.2\%) で，そのうち左右対称のものが48例を占め，特に両側外 側欠損が27例に認められ，中央欠損は16例，両側全欠損 は7 例であったとい5。著者らが追加渉猟した36例の5 ち，鎖骨欠損について記載が明らかなものは24例で，全 例両側性欠損であった，その5ち左右対称的に現れたも のは20例で，その内訳は外側欠損11例，内側欠損 1 例, 中央欠損 1 例，全部欠損 5 例，内外側欠損 2 例であっ た. 著者らの症例 1 は左右対称性に内外側端の欠損を認 めたが, 症例 2 は右側の全部欠損と左側の外側端の欠損 を認めた。

骨盤の変化は，若年者では腸骨，仙骨，恥骨間の疹合 不全がみられ，特に恥骨枝の形成不全が著明である。成 人でも，仙腸関節の開大や恥骨結合面の㒕開などがみら れることも比較的多く，一般に少成長のため狭骨盤を呈 するが，その程度は種々に存在するよらである。

他の骨格の変化では, 脊椎破裂, 脊椎側彎, 手根骨, 足根骨，手指骨，および足趾骨の形成遅延等が多く報告 されているが，これらの変化も種々に存在するよらであ る.

また本症には，知能障害やてんかんを合併した報告ら) 
もあるが，本症患者の知能は一般に正常で本症との関係 は不明である。

本症の遺伝性は古くから注目されており，欧米では多 くの家族的発症例が報告され，その遺伝形式は常染色体 による優性遺伝であると考只られている34,45)。しかし， ごくまれな常染色体性劣性遗伝を示した例も報告され， 渡部 ${ }^{29}$ は本症の遺伝形式には常染色体性優性遗伝と常 染色体性劣性遗伝とがあり，遗伝子的異型性の存在が示 唆されると述べている。また，遺伝関係を認めない多く の散発例も報告され， Rhinehart は本症に mutations dysostose の名称を与光, Schuch らによれば15.9〜53.9 \%の散発例があるといわれている5)

本邦に打ける家族的発症例は，有瀧ら5)によれば89例 のうち18家系に47例であり，散発例は43例であったとい われ，亀谷ら ${ }^{8)}$ によれは 117 例のうち遗伝関係が明らか なものは23例で19.7\%であったと報告している。また， 亀谷らの集計では親子 2 代の発現した場合は第 2 代目の みを遗伝による症例としているため，有瀧らの報告より も少数となっている.

前述のように著者らは，先人の涉猟した報告例 5 ,8) と ともに，自験例を加えて 153 例を集めたが，そのうち親 子に発症したものは，25家系に50例で全体の $32.7 \%$ あ った（表6）。しかし，これらの他に詳細が不明のため 報告例として取り扱われなかったものが12例存在するの で，これを加えると 165 例中62例 (36.2\%) は家族的発

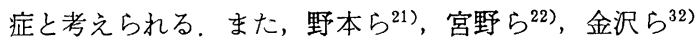
は, 両親については不明であるが同胞内での発症例を報 告している。実際には, このような遺伝疾患について家 族歴を詳細に調査することは困難な場合が多く, 同胞内 の発症や種々の不全型が存在することを考兄合わせれ ば，家族的発症例はさらに多いと考えられる，ちなみ に, 自験例の症例 2 の同胞について子精査を行ったが, 異常所見は認められなかった。症例 1 の両親, 同胞, 配 偶者については精查の機会が得られなかったが, 詳細な 問診により本症はほぼ否定された。

本症の染色体検査についての報告は, 渡辺ら ${ }^{28)}$, 本田 $5^{33)}$, 倉科 $5^{37)}$, 落合 ${ }^{49}$, 佐藤 $5^{50)}$ によっってなされ ているが, 佐藤らの1例を除けば, いずれも数と形態に 異常は認められていない，佐藤らは $\mathrm{G}$ 群短腕の延長を認 めたが, 本症との関連は不明としている. 自験例 2 例に ついても異常は認められず, 本症と染色体異常との関係 は否定的であった。

\section{結}

語

今回著者らは，母子に発現した鎖骨頭蓋異骨症を経験 したので報告した。また，先人が涉猟した本邦報告例を基 礎に，自験例を含めて153例を集め文献的考察を行った.

1）本症の特徵的所見である頭蓋骨，鎖骨，骨盤など
の形成不全や，口腔領域での異常は症例により種々の程 度に現れ，多くの不全型の存在を示唆した。

2 ）本邦報告例153例のらち，親子に発症したものは, 25 家系に50例で，全体の $32.7 \%$ であった。しかし，同胞 内での発症例や多くの不全型が存在することを考台合わ せると, さらに詳しい家系調査に上り家族的発症例は增 加するであるらと推察された。

本論文の要旨は, 第28回日本口腔外科学会総会に拈い て報告した。

\section{引用 文 献}

1）木下 功，原 浩三，他：両㑡鎖骨欠損を伴な 5 全身性骨発育異常症 (Dysostosis cleidocranialis)の蒾科学的箐察. 口病誌 14:111-117 1940.

2) Kalliala, E. and Taskin, P.J.: Cleidocranial dysostosis, Report of six typical cases and one atypical case. Oral Surg 15: 808-822 1962.

3) G.W. Oatis Jr., G.R. Robertson, et al.: Cleidocranial dysostosis with mandibular cyst. Report of a case. J Oral Surg 40: 62-67 1975.

4) R.P. Hylton Jr. and J.E. Albright: Cleidocranial dysostosis: report of case. J Oral Surg 28: 682-685 1970.

5) 有㴰世界蓈, 安坐間苝, 他: Dysostosis Cleidocranialis の母子例，本邦報告 89 例の锶察. 小児科臨床 29: 401-409 1976.

6）遠藤寺宗徳監修：現代小児科学大系 9 . 中山書 店, 東京, 1969, 201-204頁。

7) 佐藤道雄, 小宅健雄, 他: Dysostosis cleidocranialis の1 例。小児科臨床 15: 602-606 1962.

8）亀谷明秀, 野村寿男, 他: 鎖骨頭蓋異骨症の 1 例。口科誌 29: 483-492 1980 .

9）梶隆一, 速 利隆, 他: 鎖骨頭蓋異骨症の 1 例. 日外誌 27: 774-785 1981 .

10) 下里常弘, 待田順治, 他: Dysostosis cleidocranialis の1 例。口科誌 16: 348-360 1967.

11）渡辺信彦, 幸治敏與 : Dysostosis cleidocranialis. 小児科 13: 663-668 1972.

12）永井春三，火石俊夫：Dysostosis cleido-cranialis 飞就て。綜合臨床 7: 179-185 1958.

13）木村光孝, 原田隆文, 他：鎖骨頭蓋異骨症の菌 科学的所見。九州隧会誌 25: 634-641 1972.

14）園山昇, 佐藤田鹤子, 他：Dysostosis cleidoclanialis の1例について。 日外誌 23：2672721977.

15）西村章, 高木信雄, 他: Cleidocranial dysostosis 91 例。荬放 17: 159-162 1977.

16）西村修, 原田孝久, 他: Cleidocranial dysostosis 91 例 (抄). 日口外誌 25：443 1979 .

17）田中勉, 井上一男, 他: Cleidocranial dysostosis の 2 症例 (抄). 日口外誌 25：1638 1979 . 
18）中澤敏旦, 中澤望典: Cleidocranial dysostosis の 1 例. みちのく歯学誌 10: 37-39 1979.

19）田中勇三, 安藤雅史, 他 : 生後 5 か月より観察 した Cleidocranial dysostosis 6 歳男児の 1 例 (抄)。小児科診療 43：926 1980 .

20）見崎 徹, 京田直人, 他 : 鎖骨頭蓋異骨症の 1 例 (抄). 日外誌 26: 17011980 .

21）野本泰正, 土屋恵一，他 : Cleidocranial dysostosis の姉妹例(抄).小児科診寮 43:674 1980 .

22）宮野前建，吉光千記：鎖肛をはじ種々の合併 症を伴った Cleidocranial dysostosis の兄妹例 (抄). 日小児会誌 84: 2971980 .

23）広瀬永康，野原義弘，他：多くの過剩茵を伴っ た Cleidocranial dysostosis の1例。小児来誌 19: 106-114 1981 .

24）許斐博史, 舟橋满寿子, 他 : Cleidocranial dysostosis の母子例. 小児科診療 46:127-130 1983.

25）山川義兑, 高野噗昭, 他：家族的にみられた Dysostosis cleidocranialis (抄). 口科誌 $30: 678$ 1981.

26）滝川幹男，富田陽二：Cleidocranial dysostosis の 1 例 (抄). 口科誌 $30: 6781981$.

27）深沢裕文, 長谷川正文, 他: 12歯の埋伏過剩永 久歯を有する骨格型下䫇前突の 1 症例。口科誌 31: 173-182 1982.

28）渡辺 熙, 玉川輝明, 他 : 鎖骨頭蓋形成不全症 (cleidocranial dysostosis)の 3 例. 脳と発達 14: 71-76 1982.

29）渡部 健, 杉浦保夫: Cleidocranial dysplasia 一 3 代10名化発症した 1 家系報告とその遗伝 的考察——臨整外 17: 1245-1254 1982.

30）楊 栄展, 三吉聖一朗，他：親子にみられた鎖 骨頭蓋異骨症。九州菌会誌 37：645-653 1983.

31）水野智之, 北島晴比古, 他: 多数の埋伏菌を 伴った鎖骨頭䔮異骨症の 1 例。 日口外誌 29: 2333-2341 1983.

32）金沢治樹，宮沢政義，他：鎖骨頭蓋異骨症の 1 例 (抄)。口科誌 33：164 1984 .

33）本田武司，中島泰臣，他：鎖骨欠損を伴 5 多数 畨埋伏の 1 例。日口外誌 23：138-143 1977.

34) Koch, P.E. and Hammer, W.B.: Cleidocranial dysostosis: review of the literature and report of case. J Oral Surg 36: 39-42 1978.

35）持山爾之助：Dysostosis cleido-cranialis に依る 多発性埋伏歯及び其の他の所見を有する 1 例に 就て。口科誌 5：238-244 1956.

36）柳沢 虽，石川富士郎：家族的にみられた Dysostosis cleidocranialis のX線像（抄）。 日医故 会誌 29：9301969.

37）倉科憲治，武田進，他：家族的に見られた Cleidocranial dysostosis. 口科誌 27：123-131 1978.

38）朝倉武邦，山口富二雄，他：上䫇前茵部に乳歯 過剩菌々永久畨埋伏過剩料を有する 1 症例。茵 科学報 79: 303-306, 1979.

39）関本恵一, 中西孝一, 他 : 21畨の埋伏歯を有す る鎖骨頭蓋異骨症の 1 例。口科誌 19: 966-972 1970.

40）宇賀春雄, 久野吉雄, 他：上下顎に多数の㐘牙 の埋伏が認められた 2 症例について，日口外訫 17: 465-470 1971.

41）遠藤 孝, 龟谷哲也, 他：上下顎左右小曰歯部 に 6 本の過剩曾を有する稀有なる 1 例，口科訫 18: 121-125 1969.

42) Hesse: 1) より引用.

43）本橋正史，坂田慧昭，他：鎖骨頭蓋異骨症の 2 症例について。少菌誌 13：65-71 1975.

44）河野幸它, 小林 博, 他 : Dysostosis cleidocranialis の 1 例，その 1 形態的所見について(抄). 迷科学報 76: 1962-1963 1976.

45) Douglas, B.L. and Greene, H. J.: Cleidocranial dysostosis: report of case. J Oral Surg 27: 41-43 1969.

46）小池宣之, 山田竜作：鎖骨頭蓋骨形成不全 (cleidocranial dysostosis) のレ線像について （抄），日医放会誌 28：1084-1085 1968 .

47）水田隆三, 笹川広明, 他: Familial cleidocranial dysostosis の 2 家系。小児科 12:977-982 1971.

48) 北川敏夫, 浅山滉, 他: Dysostosis cleidocranialis の 2 例(抄). 日外会誌 74: 2011973 .

49）落合靖一, 浅野秀明, 他: 敛骨頭蓋異骨症の遗 伝学的研究。小児歯誌 1：82-85 1963.

50）佐藤公彦, 㴖池世史郎, 他 : Cleidocranial dysostosis の 1 例. 九州荘会訰 22: 249-258 1968. 